\title{
CENTENARY OF HJALMAR AUGUST SCHIÖTZ
}

ON February 9, 1950, one hundred years after his birth, a statue of the late Professor Schiötz was unveiled at the Oslo University Eye Clinic by Norwegian oculists. Having graduated in 1877, Schiötz worked at the Rikshospital for about two years, and then proceeded to study ophthalmology under Fuchs in Vienna and Javal in Paris. It has been aptly stated in Norway that Schiötz, with his lively

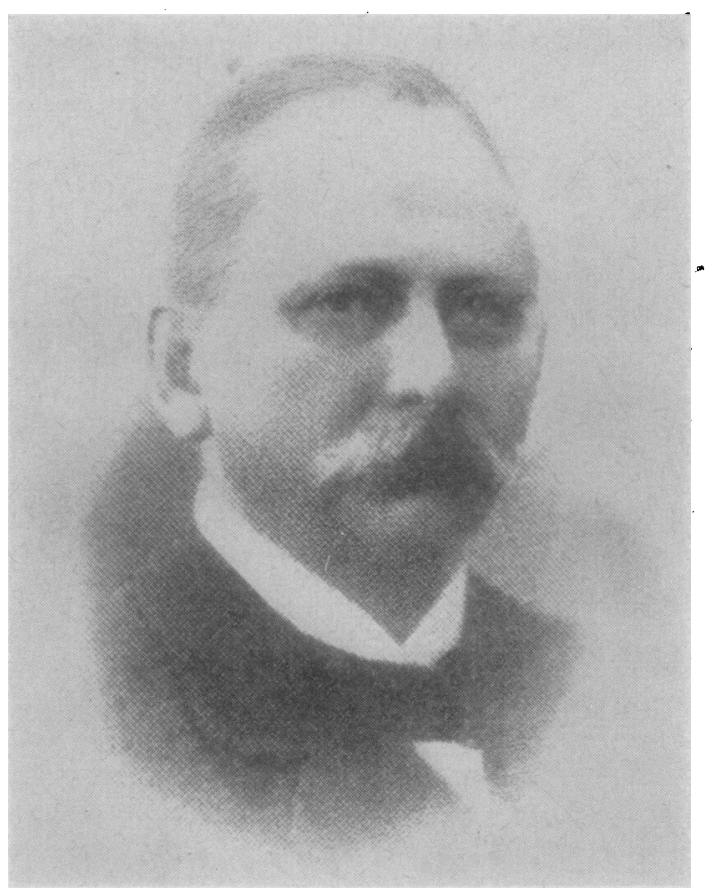

HJALMAR AUGUST SCHIÖTZ

intelligence, was thus enabled to absorb German thoroughness together with Gallic dexterity of thought. $\mathrm{He}$ assisted Javal in making the ophthalmometer, attended congresses in London and Milan, and returned to Oslo in 1881. Two years later he was awarded the M.D. degree for a thesis dealing with certain óptical features of the cornea.

Schiötz became the first Norwegian professor of ophthalmology in 1901. Before thăt date he hád made a self-registering perimeter as well as a modified ophthalmoscope, and he now proceeded to evolve the famous tonometer. It will be recalled that he was a 
resourceful craftsman, and that models of all these inventions were fashioned by his own hands in the workshop built on to his home. As time went on, the demands of teaching, writing, and private practice precluded him from much personal contact with his colleagues abroad, but his fame spread far and wide.

One keynote of Schiötz's character was an intellectual austerity which made him eschew the plaudits of the multitude. Showmanship he despised, but his personal integrity, linked with clinical acumen and skill in surgery, built for him a vast reputation among ophthalmologists all over the world. The memory of his inventiveness is linked with an eponymous tonometer, but the people of Norway revere the name of Hjalmar August Schiötz chiefly for spiritual qualities, which endure longer than any machine.

\section{OBITUARY}

\section{ROBERT ERIC HENRY.}

ROBERT ERIC HENRY died suddenly in London on January 11, at the age of 51. He hailed from Sydney, Australia, where he began his medical career in 1915. After completing his first year of medicine he enlisted for war service abroad, and served with the A.N.Z.A.C. for 3 years (1916-19), receiving a knee wound while fighting in France. In 1919 he returned to his interrupted medical studies, graduated in 1923 and eventually travelled to England in 1930 for the purpose of specializing in ophthalmology.

While in London he contracted poliomyelitis, which resulted in a crippling paralysis of both legs. After 3 years' treatment he returned to London in 1935 , barely able to stand erect or to walk even a limited distance with leg calipers and his two sticks. "Nevertheless he consistently rejected any kind of commiseration, and, with his familiar smile, faced undaunted the difficulties of starting practice as an eye specialist in London.

Although precluded from surgery because that involves standing unaided, he served three London Eye Hospitals faithfully and well. Throughout the second world war he remained in his London flat, which became a haven of refuge for his many Service friends, and mean while he worked harder than ever, ignoring London's wartime discomforts and dangers. The strain of working daily to the limit of his physical endurance, however, could not be maintained indefinitely, and the sad occurrence of a cerebral haemorrhage prematurely terminated this gallant determination to succeed in practice and be independent to the end. Eric Henry is mourned by all who knew him ; his cheery generous nature and steadfast courage in adversity will long be remembered.

H. H. S. 